\title{
Extraction and Purification of C-phycocyanin from Spirulina platensis in Conventional and Integrated Aqueous Two-Phase Systems
}

\author{
Francine S. Antelo, Andréia Anschau, Jorge A. V. Costa and Susana J. Kalil* \\ Departamento de Química, Universidade Federal do Rio Grande, 96201-900 Rio Grande-RS, Brazil
}

\begin{abstract}
Extrato aquoso de C-ficocianina de Spirulina platensis, com e sem resíduos celulares, foi purificado em sistema aquoso bifásico (SAB) polietilenoglicol (PEG)/fosfato de potássio variando-se a massa molar do $\mathrm{PEG}$, a $\mathrm{pH}$ 6, mais promissor do que a $\mathrm{pH}$ 7. Para os ensaios realizados com cada massa molar, com diferentes percentuais de PEG e sal, as concentrações $\left(\mathrm{mg} \mathrm{mL}^{-1}\right)$, as purezas (OD 620/OD 280) e os coeficientes de partição da C-ficocianina de cada sistema foram determinados e comparados. O processo para a purificação primária de C-ficocianina intracelular com resíduos celulares (integrado), composto por $15 \%$ de PEG 1500 e $13 \%$ de fosfato de potássio de $5 \%$ de PEG 4000 e $18 \%$ de sal, alcançaram concentrações de C-ficocianina de, respectivamente, 1,60 e $2,67 \mathrm{mg} \mathrm{mL}^{-1}$ na fase de topo. As purezas foram de $0,73 \mathrm{e} 0,79$, respectivamente, valores superiores aos obtidos nos sistemas sem resíduos celulares.
\end{abstract}

Crude C-phycocyanin extracts from Spirulina platensis, with and without cell debris, were purified in aqueous two-phase systems (ATPS) varying the molar mass of the PEG, at pH 6, more promising than at $\mathrm{pH}$ 7. For the assays carried out with each molar mass, with distinct percentages of PEG and salt, the concentrations ( $\mathrm{mg} \mathrm{mL}^{-1}$ ), purities (OD 620/OD 280) and C-phycocyanin partition coefficients of each system were determined and compared. The process for the primary purification of intracellular C-phycocyanin with cell debris (integrated), composed of $15 \%$ of PEG 1500 and $13 \%$ of potassium phosphate and 5\% of PEG 4000 and $18 \%$ of salt, produced C-phycocyanin concentrations of, respectively, 1.60 and $2.67 \mathrm{mg} \mathrm{mL}^{-1}$ in the top phase. The purities were of 0.73 and 0.79 respectively, values higher than those obtained in the systems without cells.

Keywords: C-phycocyanin, aqueous two-phase system, purity, protein, polyethylene glycol

\section{Introduction}

The cyanobacterium Spirulina platensis has been the focus of important biotechnological research due to its economical, ecological and nutritional importance. This microalga has great potential in the production of food and related nutritional materials, such as colouring agents, vitamins, $\gamma$-linolenic acid and enzymes. ${ }^{1}$ Amongst the proteins present in Spirulina platensis are the phycobiliproteins, a family of hydrophilic, brilliantly coloured and stable fluorescent pigment proteins that can be classified into three main groups: phycocyanin (C-PC), phycoerythrin (C-PE) and allophycocyanin (C-APC) depending on the inherent colour and absorbance properties. ${ }^{2,3} \mathrm{C}$-phycocyanin is the major component of the phycobiliprotein family. It is not only used as a nutritive ingredient and natural dye in foods (chewing gums, dairy

*e-mail: dqmsjk@ furg.br products, ice sherbets, jellies etc) and cosmetics in Japan, Thailand and China, but also used as a potential therapeutic agent in oxidative diseases and as a fluorescent marker in biomedical research. ${ }^{4-10}$

However, the production of intracellular proteins, such as C-phycocyanin, presents a series of practical problems in the downstream process. The separation processes generally involve the liberation of each product by mechanical or chemical breakage, followed by the removal of cell debris and some contaminants by centrifugation or membrane filtration. The quantitative elimination of cell debris and some contaminants in each unit operation can considerably hinder the accomplishment of the process due to the complex nature of the products, and the pollutants present on the inside of the cell can exercise a negative impact on the recovery process. ${ }^{11}$ Thus an integrated process, where two unit operations are combined into one, offers a considerable potential benefit in the recovery of intracellular protein products. ${ }^{12}$ Process integration of 
cell disruption or extraction with primary recovery unit operations could enhance both the yield and molecular quality of protein products.

An aqueous two-phase system (ATPS) is the most economical downstream technique that can be used for large-scale protein extraction and purification. ${ }^{18}$ Their technical simplicity, ease of operation and scale-up, make them very attractive for industrial applications. In these systems, aqueous phases are formed when two hydrophilic, but immiscible polymers, such as a polymer and a salt are mixed above their critical concentrations. Although a variety of ATPS is large, the most applied to the liquidliquid extraction are made of polyethylene glycol (PEG)/ dextran and polyethylene glycol (PEG)/salt (phosphate, sulphate, citrate), when considering important factors in terms of industry such as cost and recyclability of reagents, time of phase separation, possibility of sterilization and non-toxic range of application. The biomolecules are added to the system and are directed, preferentially, to one of the phases. This partitioning behaviour of a protein in ATPS is influenced by factors including the polymer molecular weight, polymer/salt concentrations, system $\mathrm{pH}$ and temperature, and the size and the hydrophobic/hydrophilic nature of the biomolecule, amongst others. ${ }^{13-19}$

Advances have been made in the development of robust ATPS processes, but their adoption in integrated processes, which involves extraction and purification primary steps, has not been widely reported. ${ }^{12,20}$

The aim of this work was to study an integrated extraction and purification process of C-phycocyanin from Spirulina platensis using the ATPS polyethylene glycol (PEG)/potassium phosphate, experimenting with different polyethylene glycol molar masses, and compare the results with those from the conventional system without cell debris, so as to obtain C-phycocyanin extracts with greater concentration and purity in a single step.

\section{Experimental}

\section{Culture conditions for Spirulina platensis}

Spirulina platensis LEB $52^{21}$ was cultivated in $450 \mathrm{~L}$ open outdoor photo-bioreactors under uncontrolled environmental conditions in the south of Brazil. During these cultivations, the water was supplemented with $20 \%$ Zarrouk $^{22}$ synthetic medium, with an initial biomass concentration of $0.30\left(\mathrm{~g} \mathrm{~L}^{-1}\right)$. Samples were taken every $24 \mathrm{~h}$ to determine the biomass concentration via optical density measurements at $670 \mathrm{~nm}$ in a spectrophotometer (FEMTO spectrophotometer 700 Plus) according to Costa et $a l .{ }^{23}$ At the end of the cultivation period, the biomass was recovered by filtration, pressing and extrusion, dried at $50{ }^{\circ} \mathrm{C}$ for $6 \mathrm{~h}$, frozen at $-18{ }^{\circ} \mathrm{C}$, ground in a ball mill and sieved (the perforations on the sieve being 150 mesh).

\section{C-Phycocyanin extraction}

C-phycocyanin was extracted using the system without cell debris, called conventional, according to the conditions established by Silveira et al. ${ }^{24}$ After extraction, the suspension was centrifuged and vacuum filtered and the supernatant collected. In the integrated process for primary purification with cell debris, the crude C-phycocyanin extract was substituted by the dried biomass suspension of Spirulina platensis, macerated and sifted, with a biomass: solvent ratio according to Silveira et al..$^{24}$

\section{Polyethylene glycol molar mass (PEG)}

For the C-phycocyanin purification process in the PEG/potassium phosphate system, three molar masses of polyethylene glycol, 1500, 4000 and $6000\left(\mathrm{~g} \mathrm{gmol}^{-1}\right)$ (Labsynth LTDA, Diadema, SP, Brazil) were used.

\section{Determination of binodal curves}

The binodal curves of the systems composed of PEG 1500,4000 or 6000 and potassium phosphate $(30 \%, \mathrm{~m} / \mathrm{m})$ were built according to the methodology described by Albertson. ${ }^{17}$

\section{Preparation of the aqueous two-phase systems}

The phase systems were prepared in graduated centrifuge tubes by weighing the PEG 1500,4000 or 6000 and adding a stock solution of $30 \%(\mathrm{~m} / \mathrm{m})$ potassium phosphate. The potassium phosphate stock solution consisted of a mixture of appropriate amounts of $\mathrm{KH}_{2} \mathrm{PO}_{4}$ and $\mathrm{K}_{2} \mathrm{HPO}_{4}$ (Labsynth LTDA, Diadema, SP, Brazil) in order to obtain the desired $\mathrm{pH}$. The systems were vortex-mixed (Phoenix AP 56) for dilution of the PEG and then left to rest for phase separation. For the system without cell debris (conventional), 20\% (v/v) crude C-phycocyanin extract was added to the system. For system with cell debris (integrated), 20\% (m/v) dried biomass suspension was added to the system, in the same way. Both systems, made up to $20 \mathrm{~g}$ by the addition of water, were centrifuged (Presvac DCS 16 RV) at $1800 \mathrm{~g}$ for $20 \mathrm{~min}$ to speed up phase separation. All tests were performed in triplicate.

The top and bottom phases were separated, the volumes measured and the C-phycocyanin concentrations calculated. 
Reference systems for each trial were prepared without the addition of crude C-phycocyanin extract or dried biomass suspension, and the phases, after separation, were submitted to spectrophotometric readings at $280 \mathrm{~nm}$ and the values subtracted from the original system reading.

\section{Study of the $\mathrm{pH}$ used in the C-phycocyanin purification in ATPS}

C-phycocyanin purification in ATPS, without cell debris, was studied at pH 6.0 and 7.0 for the $21 \%$ PEG and $10 \%$ salt composition system (Table 1 ), the mid point of the binodal curve, applicable to all the polymer molecular mass variations, 1500,4000 or $6000\left(\mathrm{~g} \mathrm{gmol}^{-1}\right)$. The trials were done in duplicate (Table 1).

Table 1. Comparison of the purification factors (PF) and recoveries (RC) of C-phycocyanin, volume ratios (Vr) and partition coefficients $\left(\mathrm{K}_{\text {part }}\right)$ obtained for the systems composed of $21 \%$ of polyethylene glycol 1500 , 4000 or $6000\left(\mathrm{~g} \mathrm{gmol}^{-1}\right)$ and $10 \%$ of potassium phosphate, at $\mathrm{pH}$ values of 6.0 and 7.0

\begin{tabular}{lccccccc}
\hline $\begin{array}{l}\text { PEG/ } \\
\left(\text { g gmol }^{-1}\right)\end{array}$ & pH & Phase & Purity & PF & RC $(\%)$ & Vr & $\mathrm{K}_{\text {part }}$ \\
\hline 1500 & 6.0 & T & 0.77 & $1.3 \pm 0.09$ & $86.7 \pm 5.4$ & 2.4 & $\propto$ \\
& & B & 0.01 & 0 & 0 & & \\
& 7.0 & T & 0.61 & $0.9 \pm 0.03$ & $97.3 \pm 0.34$ & 2.7 & $\propto$ \\
& & B & 0.07 & $0.1 \pm 0.04$ & $0.1 \pm 0.08$ & & \\
\hline 4000 & 6.0 & T & 0.71 & $1.2 \pm 0.07$ & $94.9 \pm 1.19$ & 3.0 & $\propto$ \\
& & B & 0.06 & $0.1 \pm 0.06$ & 0 & & \\
& 7.0 & T & 0.68 & $1.0 \pm 0.02$ & $88.4 \pm 9.19$ & 2.5 & $\propto$ \\
& & B & 0.01 & $0 \pm 0.03$ & 0 & & \\
\hline 6000 & 6.0 & T & 0.88 & $1.5 \pm 0.05$ & $59.4 \pm 1.31$ & 2.0 & 65.97 \\
& & B & 0.06 & $0.1 \pm 0.02$ & $0.5 \pm 0.02$ & & \\
& 7.0 & T & 0.61 & $0.9 \pm 0.05$ & $86.1 \pm 4.63$ & 2.2 & $\propto$ \\
& & B & 0.01 & 0 & $0.4 \pm 0.46$ & & \\
\hline
\end{tabular}

$>100$ : value over $100 ; \propto$ : value tending to infinite, C-phycocyanin concentration in the bottom phase inferior to the detection limit $\left(10^{-5} \mathrm{mg} \mathrm{mL}^{-1}\right)$.

\section{ATPS composition for the integrated process}

Table 2 presents the values for PEG (\%) and potassium phosphate $(\%)$ used in the study for the primary recovery and purification of intracellular phycocyanin, conventional and integrated, varying the molar mass of the polymer. These assays were carried out at the previously selected $\mathrm{pH}$ value. The trials proposed to study different compositions for the ATPS, involving high and low percentages of PEG and salt, each assay being carried out in triplicate. The
Table 2. Values for PEG (\%) and potassium phosphate (\%) used in each assay for ATPS systems with (integrated) and without cell (conventional), for each molar mass of the polymer

\begin{tabular}{lcccccc}
\hline & \multicolumn{2}{c}{ PEG 1500} & \multicolumn{2}{c}{ PEG 4000} & \multicolumn{2}{c}{ PEG 6000 } \\
Assay & PEG & SALT & PEG & SALT & PEG & SALT \\
$(\%)$ & $(\%)$ & $(\%)$ & $(\%)$ & $(\%)$ & $(\%)$ \\
\hline 1 & 38 & 5 & 38 & 5 & 38 & 5 \\
2 & 25 & 8 & 25 & 8 & 25 & 8 \\
3 & 15 & 13 & 15 & 13 & 15 & 13 \\
4 & 5 & 18 & 5 & 18 & 5 & 18 \\
5 & 16 & 20 & 16 & 20 & 16 & 20 \\
\hline
\end{tabular}

same dry biomass suspension of Spirulina platensis was used in all the trials.

\section{C-phycocyanin concentration}

According to Bennett and Bogorad, ${ }^{25}$ the C-phycocyanin concentration $(\mathrm{PC})$ was defined as:

$\mathrm{PC}=\frac{\left[\mathrm{OD}_{615}-0.474 \times \mathrm{OD}_{652}\right]}{5.34}$

where $\mathrm{PC}$ is the $\mathrm{C}$-phycocyanin concentration $\left(\mathrm{mg} \mathrm{mL}^{-1}\right)$, $\mathrm{OD}_{615}$ is the optical density of the sample at $615 \mathrm{~nm}$ and $\mathrm{OD}_{652}$ is the optical density of the sample at $652 \mathrm{~nm}$.

\section{C-Phycocyanin purity}

The C-phycocyanin purity (EP) was calculated spectrophotometrically using the following relationship. ${ }^{2}$

$\mathrm{EP}=\frac{\mathrm{OD}_{620}}{\mathrm{OD}_{280}}$

where $\mathrm{OD}_{620}$ is the optical density of the sample at $620 \mathrm{~nm}$ and $\mathrm{OD}_{280}$ is the optical density of the sample at $280 \mathrm{~nm}$. This relationship is indicative of the C-phycocyanin extract purity with respect to most forms of contaminating protein. The absorbance at $620 \mathrm{~nm}$ indicates the C-phycocyanin concentration, while that at $280 \mathrm{~nm}$ is due to the total concentration of proteins in the solution. ${ }^{26}$

\section{C-Phycocyanin purification factor}

The purification factor was defined as:

$\mathrm{PF}=\frac{\mathrm{EP}_{\mathrm{p}}}{\mathrm{EP}_{\mathrm{c}}}$

where $\mathrm{PF}$ is the purification factor, $\mathrm{EP}_{\mathrm{p}}$ is the extract purity after the purification process and $\mathrm{EP}_{\mathrm{c}}{ }_{\mathrm{p}}$ is the purity of the crude extract. 


\section{C-Phycocyanin recovery}

The extract recovery (\%) was defined as:

$\mathrm{RC}=\frac{\left[\mathrm{PC}_{\text {phase }} \times \mathrm{V}_{\text {phase }}\right]}{\left[\mathrm{PC}_{\text {crude_ext }} \times \mathrm{V}_{\text {in }}\right]} \times 100$

where $\mathrm{PC}_{\text {phase }}$ is the $\mathrm{C}$-phycocyanin concentration in the phase considered $\left(\mathrm{mg} \mathrm{mL}^{-1}\right), \mathrm{PC}_{\text {crude_ext }}$ is the $\mathrm{C}$-phycocyanin concentration in crude extract $\left(\mathrm{mg} \mathrm{mL}^{-1}\right), \mathrm{V}_{\text {phase }}$ is the volume of the phase considered $(\mathrm{mL})$ and $\mathrm{V}_{\text {in }}$ is the initial volume of the extract added $(\mathrm{mL})$.

\section{C-phycocyanin partition coefficient}

The partition coefficient $\left(\mathrm{K}_{\text {part }}\right)$ for C-phycocyanin was calculated using the following equation: ${ }^{17}$

$\mathrm{K}_{\text {part }}=\frac{\mathrm{PC}_{\text {top }}}{\mathrm{PC}_{\text {bot }}}$

where $\mathrm{PC}_{\text {top }}$ and $\mathrm{PC}_{\text {bot }}$ are, respectively, the C-phycocyanin concentrations in the top and bottom phases $\left(\mathrm{mg} \mathrm{mL}^{-1}\right)$.

\section{Volume ratio}

The volume ratio ( $\mathrm{Vr}$ ) was given by the ratio between the top phase and bottom phase volumes: ${ }^{27}$

$\mathrm{Vr}=\frac{\mathrm{V}_{\text {top }}}{\mathrm{V}_{\text {bot }}}$

where $\mathrm{V}_{\text {top }}$ is the $\mathrm{C}$-phycocyanin volume in the top phase $(\mathrm{mL})$ and $\mathrm{V}_{\text {bot }}$ is the C-phycocyanin volume in the bottom phase $(\mathrm{mL})$, after the purification process.

\section{Results and Discussion}

\section{pH study in C-phycocyanin purification}

The C-phycocyanin purification studies were done considering $\mathrm{pH}$ values of 6.0 and 7.0, values where the protein is stable according to Sarada et al. ${ }^{5} \mathrm{C}$-phycocyanin have a isoeletric point value of $5.8,{ }^{28} \mathrm{pH}$ value in which there is balance between the positive and negative charges of the ionic groups of a protein. The C-phycocyanin concentrated in the top phase of the systems at both $\mathrm{pH}$ values (see Table 1). According to Patil et al. ${ }^{19}$ this behaviour means that it was more soluble in PEG rich phase, presenting hydrophobic character, yet increased by its negative charge ( $\mathrm{pH}$ value above $\mathrm{pI}$ value of C-phycocyanin) in addition to the volume available free at top phase of the system. This preference for the top phase resulted in a high partition coefficient of about 100 or over, for all the systems studied.
The initial purity of the crude C-phycocyanin extract was 0.59 at $\mathrm{pH} 6.0$ and 0.68 at $\mathrm{pH}$ 7.0. Purification of the C-phycocyanin was possible for the $\mathrm{pH} 6.0$ systems, since the purification factor was over 1, being 1.3, 1.2 and 1.5-fold, respectively, for the PEG molar masses considered of 1500 , 4000 and 6000 (see Table 1). Favourable results were not obtained at $\mathrm{pH} 7.0$, and at $\mathrm{pH} 6.0$ it was observed that the lower the volume ratio, $\mathrm{Vr}$, the higher the purification factor obtained for the C-phycocyanin. A decrease in the top phase brings, as a consequence, an increase in the bottom phase, it being possible that a greater part of the contaminating proteins would migrate to this free volume, contributing to the increase in the purification factor of the target-protein, due to the high affinity of the C-phycocyanin for the top phase and its permanence in it. For the lowest $\mathrm{Vr}$ value, corresponding to the lowest $\mathrm{K}_{\text {part }}$ value, the possibility of trace migration of the target-protein to the bottom phase increases, which would consequently lower its recovery in the upper phase, rich in PEG. Still, in the pH 6 experiments using PEGs 1500 and 6000, the purity of C-phycocyanin was higher than that obtained under the best conditions for purification by precipitation studied by Silva et al., ${ }^{29}$ reaching values of 0.77 and 0.88 . Thus due to these results, $\mathrm{pH} 6.0$ was chosen to compare the conventional and integrated C-phycocyanin purification systems by ATPS.

\section{Comparative study of the conventional and integrated ATPS}

Five different ATPS formulations were selected for each molar mass of the polymer for a direct comparison of the performance of the conventional system of C-phycocyanin purification and the integrated system of extraction and purification of the protein (see Tables 3, 4 and 5). For the conventional processes, the initial purity of the crude phycocyanin extract was of 0.44 . It was observed that once again the $\mathrm{C}$-phycocyanin remained in the top phase, rich in PEG, of the integrated systems, as well as in the conventional purification systems, according to the high values obtained for $\mathrm{K}_{\text {part }}$. The cells debris stayed in the top/bottom interface of the integrated systems after the extraction process, for all the PEG molar masses studied: 1500, 4000 or 6000 Da. For the integrated systems using the PEG molar masses of 1500 and 4000 (see Tables 3 and 4), the C-phycocyanin concentrations obtained in the top phases were higher than those in the same phase of the conventional systems. However for the integrated systems using PEG 6000 (see Table 5), only the first three assays showed this increase in protein concentration. The increase in C-phycocyanin concentration obtained when submitted to the integrated systems of extraction and purification could be due to the non-use of stages that could retain part of the extracted C-phycocyanin, along with membrane filtration processes, amongst others, applied prior to the use of conventional ATPS or favoring by the composition of the extraction system. 
Table 3. Comparison of the ATPS systems PEG 1500/potassium phosphate with (integrated) and without cell (conventional), with respect to the concentration $\left(\mathrm{mg} \mathrm{mL}^{-1}\right)$, purity and partition coefficient $\left(\mathrm{K}_{\text {part }}\right)$ of the protein and the volume ratio $(\mathrm{Vr})$ of the phases

\begin{tabular}{lcccccccc}
\hline & \multicolumn{3}{c}{ Conventional system } & & & \multicolumn{2}{c}{ Integrated system } \\
Assay & $\begin{array}{c}\text { Concentration/ } \\
\left(\mathrm{mg} \mathrm{mL}^{-1}\right)\end{array}$ & Purity & $\mathrm{Vr}$ & $\mathrm{K}_{\text {part }}$ & $\begin{array}{c}\text { Concentration/ } \\
\left(\mathrm{mg} \mathrm{mL}^{-1}\right)\end{array}$ & Purity & $\mathrm{Vr}$ & $\mathrm{K}_{\text {part }}$ \\
\hline 1 & 0.79 & 0.45 & 14.4 & $>100$ & 2.56 & 0.52 & 20.1 & $\propto$ \\
2 & 0.94 & 0.49 & 5.4 & $>100$ & 2.17 & 0.64 & 5.5 & $\propto$ \\
3 & 1.27 & 0.48 & 2.1 & $>100$ & 1.60 & 0.73 & 1.2 & $\propto$ \\
4 & 1.52 & 0.51 & 1.2 & $>100$ & 2.41 & 0.58 & 1.4 & $>100$ \\
5 & 1.44 & 0.48 & 1.7 & $\propto$ & 2.25 & 0.58 & 1.3 & $>100$ \\
\hline
\end{tabular}

$>100$ : value over $100 ; \propto$ : value tending to infinite, C-phycocyanin concentration in the bottom phase inferior to the detection limit $\left(10^{-5} \mathrm{mg} \mathrm{mL}^{-1}\right)$.

Table 4. Comparison of the ATPS systems PEG 4000/potassium phosphate with (integrated) and without cell (conventional), with respect to the concentration $\left(\mathrm{mg} \mathrm{mL}^{-1}\right)$, purity and partition coefficient $\left(\mathrm{K}_{\text {part }}\right)$ of the protein and the volume ratio $(\mathrm{Vr})$ of the phases

\begin{tabular}{lcccccccc}
\hline Assay & \multicolumn{2}{c}{ Conventional system } & & & \multicolumn{2}{c}{ Integrated system } \\
$\begin{array}{c}\text { Concentration/ } \\
\left(\mathrm{mg} \mathrm{mL}^{-1}\right)\end{array}$ & Purity & $\mathrm{Vr}$ & $\mathrm{K}_{\text {part }}$ & $\begin{array}{c}\text { Concentration/ } \\
\left(\mathrm{mg} \mathrm{mL}^{-1}\right)\end{array}$ & Purity & $\mathrm{Vr}$ & $\mathrm{K}_{\text {part }}$ \\
\hline 1 & 0.79 & 0.49 & 25.9 & $\propto$ & 2.40 & 0.47 & 11.7 & $\propto$ \\
2 & 0.92 & 0.56 & 5.4 & $\propto$ & 2.00 & 0.45 & 3.7 & $\propto$ \\
3 & 1.47 & 0.52 & 2.1 & $\propto$ & 2.05 & 0.46 & 1.5 & $>100$ \\
4 & 2.02 & 0.64 & 0.8 & $\propto$ & 2.67 & 0.79 & 0.8 & $\propto$ \\
5 & 1.72 & 0.50 & 1.4 & $\propto$ & 2.39 & 0.49 & 1.0 & $\propto$ \\
\hline
\end{tabular}

$>100$ : value over 100; $\propto$ : value tending to infinite, C-phycocyanin concentration in the bottom phase inferior to the detection limit $\left(10^{-5} \mathrm{mg} \mathrm{mL}^{-1}\right)$.

Table 5. Comparison of the ATPS systems PEG 6000/potassium phosphate with (integrated) and without cell (conventional), with respect to the concentration $\left(\mathrm{mg} \mathrm{mL}^{-1}\right)$, purity and partition coefficient $\left(\mathrm{K}_{\text {parr }}\right)$ of the protein and the volume ratio $(\mathrm{Vr})$ of the phases

\begin{tabular}{lcccccccc}
\hline Assay & \multicolumn{2}{c}{ Conventional system } & & & \multicolumn{2}{c}{ Integrated system } \\
$\begin{array}{c}\text { Concentration/ } \\
\left(\mathrm{mg} \mathrm{mL}^{-1}\right)\end{array}$ & Purity & $\mathrm{Vr}$ & $\mathrm{K}_{\text {part }}$ & $\begin{array}{c}\text { Concentration/ } \\
\left(\mathrm{mg} \mathrm{mL}^{-1}\right)\end{array}$ & Purity & $\mathrm{Vr}$ & $\mathrm{K}_{\text {part }}$ \\
\hline 1 & 0.66 & 0.52 & 17.0 & $\propto$ & 2.57 & 0.44 & 11.4 & $\propto$ \\
2 & 0.99 & 0.55 & 6.5 & $\propto$ & 2.25 & 0.42 & 3.4 & $\propto$ \\
3 & 1.70 & 0.56 & 1.9 & $\propto$ & 2.47 & 0.44 & 1.4 & $\propto$ \\
4 & 2.40 & 0.56 & 3.1 & 62.4 & 1.94 & 0.48 & 0.8 & 42.4 \\
5 & 2.50 & 0.48 & 1.2 & $\propto$ & 1.72 & 0.45 & 1.1 & $\propto$ \\
\hline
\end{tabular}

$>100$ : value over 100; $\propto$ : value tending to infinite, C-phycocyanin concentration in the bottom phase inferior to the detection limit $\left(10^{-5} \mathrm{mg} \mathrm{mL}^{-1}\right)$.

With respect to purity, all the assays for the integrated system of PEG 1500/potassium phosphate reached higher values than those obtained in the conventional system of the same composition, from 14 to $52 \%$ higher, while for the system with PEG 4000, only one of the integrated system assays obtained greater purity (23\%) than that of the other system. For the ATPS of PEG 6000/potassium, phosphate the conventional system obtained greater purities for the C-phycocyanin of about 6 to 24\% in relation to the integrated systems. The integrated ATPS with PEG $1500 /$ potassium phosphate obtained in assay 3 , composed of $15 \%$ of PEG 1500 and $13 \%$ of salt, obtained 0.73 of purity for the C-phycocyanin, and that of assay 4 of the integrated system with PEG 4000/potassium phosphate, composed of $5 \%$ of polymer and $18 \%$ of salt, obtained a values of 0.79 . According to Patil et al.,$^{19}$ the purity of the
C-phycocyanin is evaluated from the ratio of the absorbances $\mathrm{OD}_{620} / \mathrm{OD}_{280}$, where a value of 0.7 or above is considered to be of alimentary degree, and this degree was reached in the above two assays, in integrated ATPSs composed of PEG 1500 or 4000 and potassium phosphate.

The integrated ATPS composed of PEG 4000 associate the best purity, 0.79, with the largest C-phycocyanin concentration in the top phase, $2.67 \mathrm{mg} \mathrm{mL}^{-1}$, thus being more efficient than the PEG 1500 system, that resulted in a purity of 0.73 and a concentration of only $1.6 \mathrm{mg} \mathrm{mL}^{-1}$ of protein in the top phase, a value $60 \%$ inferior to that obtained in the above PEG 4000 system.

The $\mathrm{Vr}$ values for the conventional and integrated processes were different. Of the different PEG molar masses studied, the behaviours of the PEG 4000 systems stand out, where the $\mathrm{Vr}$ could be correlated with the phycocyanin 
purity and concentration reached. A reduction in the top phase consequently increases the bottom phase, which can facilitate a larger part of the contaminants migrating into this free volume, thus contributing to the increase in purity of the target-protein due to the high affinity of the C-phycocyanin for the top phase and its permanence there.

\section{Conclusions}

The process integration strategy presented here demonstrated that the simultaneous extraction and primary purification of intracellular C-phycocyanin extracted from Spirulina platensis can be achieved in aqueous two-phase system, which had not previously been explored. In particular, operating conditions were established that facilitated the primary recovery and purification of C-phycocyanin directly and quickly from disrupted cells with a significant degree of purity with respect to the elimination of cell debris in a single operation. The ATPS polyethylene glycol/potassium phosphate $\mathrm{pH} 6.0$ proved to be a promising purification method applicable to C-phycocyanin. For two of the PEG molar masses studied, 1500 and 4000, under appropriate salt to polymer conditions, it was possible to reach a purity range of 0.7. Of the two types of ATPS studied, the integrated system of C-phycocyanin purification and extraction obtained greater concentrations of the target-protein in the top phase, while the cell debris remained at the interface in all the system types and compositions. The integrated system composed of 5\% of PEG 4000 and $18 \%$ of salt gave the best results for C-phycocyanin concentration in the top phase and the best purity for this protein, values of $2.67 \mathrm{mg} \mathrm{mL}^{-1}$ and 0.79 respectively, the latter value classifying it as being of alimentary degree, since the purity was above 0.7 .

\section{Acknowledgments}

This research was supported by the Coordenação de Aperfeiçoamento de Pessoal de Nível Superior (CAPES).

\section{References}

1. Rippka, R.; Deruelles, J.; Waterbury, J. B.; Herdman, M., Stanier, R. Y.; J. Chem. Microbiol. 1979, 111, 1.

2. Abalde, J.; Betancourt, L.; Torres, E.; Cid, A.; Barwell, C.; Plant. Sci. 1998, 136, 109.

3. Soni, B.; Kalawadia, B.; Trivedi, U.; Madamwar, D.; Process Biochem. 2006, 41, 2017.

4. Glazer, A. N.; Appel, G. S.; Hixson, C. S.; Bryant, D. A.; Rimon, S.; Brown, D. M.; Proc. Natl. Acad. Sci. USA 1976, 78, 428.
5. Sarada, R.; Pillai, M. G.; Ravishankar, G. A.; Process Biochem. 1999, 34, 795.

6. Cohen, Z. In Products from Microalgae: Handbook of Microalgae Mass Culture; Richmond, A. ed., CRC Press: Boca Raton, 1986.

7. Yoshida, A.; Takagaki, T.; Nishimune, T.; Biosci., Biotechnol., Biochem.1996, 60, 57.

8. Romay, C.; Aspee, A.; Pizarro, M.; Lissi, E. A.; Free Radical Biol. Med. 2000, 28, 1051.

9. Bhat, V. B.; Madyastha, K. M.; Biochem. Biophys. Res. Commun. 2000, 275, 20.

10. Rimbau, V.; Camin, A.; Romay, C.; González, R.; Neurosci. Lett. 1999, 276, 75.

11. Bierau, H.; Zhang, Z.; Lyddat, A.; J. Chem. Technol. Biotechnol. 1999, 74, 208.

12. Rito-Palomares, M.; Lyddiatt, A.; Chem. Eng. J. 2002, 87, 313.

13. Kula, M. R.; Kroner, K. H.; Adv. Biochem. Eng./Biotechnol. 1982, 24, 73 .

14. Diamond, A. D.; Hsu, J. T.; Adv. Biochem. Eng./Biotechnol. 1992, 47, 89.

15. Marcos, J. C.; Fonseca, L. P.; Ramalho, M. T.; Cabral, J. M. S.; J. Chromatogr., B 1998, 711, 295.

16. Marcos, J. C.; Fonseca, L. P.; Ramalho, M. T.; Cabral, J. M. S.; J. Chromatogr., B 1999, 734, 15.

17. Albertson, P. A.; Partitioning of Cell Particles and Macromolecules, $1^{\text {th }}$ ed., Wiley: New York, 1986.

18. Gautam, S.; Simon, L.; Biochem. Eng. J. 2006, 30, 104.

19. Patil, G.; Chetana, S.; Sridevi, A. S.; Raghavarao, K. S. M. S.; J. Chromatogr., A 2006, 15, 76.

20. Rito-Palomares, M. J.; J. Chromatogr., B 2004, 807, 3.

21. Costa, J. A. V.; Linde, G. A.; Atala, D. I. P.; Mibielli, G. M.; Krueger, R. T.; World J. Microbiol. Biotechnol. 2000, 16, 15.

22. Zarrouk, C.; PhD Thesis, University of Paris, France, 1996.

23. Costa, J. A. V.; Cozza, K. L.; Oliveira, L.; Magagnin, G.; World J. Microbiol. Biotechnol. 2002, 17, 439.

24. Silveira, S. T.; Burkert, J. F. M.; Costa, J. A. V.; Burkert, C. A. V.; Kalil, S. J.; Bioresour. Technol. 2007, 98, 1629.

25. Bennett, A.; Bogorad, L.; J. Cell. Biol. 1973, 58, 419.

26. Liu, L. N.; Chen, X. L.; Zhang, X. Y.; Zhang, Y. Z.; Zhou, B. C.; J. Biotechnol. 2005, 116, 91.

27. Bermejo, R.; Alvarez-Pez, J. M.; Acién, F. G.; Molina, E.; J. Biotechnol. 2002, 93, 73.

28. Rito-Palomares, M.; Nuñez, L.; Amador, D.; J. Chem. Technol. Biotechnol. 2001, 76, 1273.

29. Silva, L. A.; Kuhn, K. R.; Moraes, C. C.; Burkert, C. A. V.; Kalil, S. J.; J. Braz. Chem. Soc. 2009, $20,5$.

Received: October 31, 2008 Web Release Date: March 11, 2010 